\title{
Women and Small Business: Contributing to Household income and Family wellbeing
}

\author{
Mary Eru Iji*, Edem A. Ebong, Thomas A. Omang, \& Mary U. Ojong-Ejoh \\ Department of Sociology, University of Calabar, Cross River State, Nigeria
}

\begin{abstract}
The objective of the study is to examine the extent to which women involvement is small business contributes to household income and family wellbeing. The study adopted the survey research method in collecting data from 317 women from Yala Local Government Area of Cross River State, Nigeria using Cluster and Purposive sampling technique. The Survey Monkey Sample Determinant Technique was used to determine the sample size for the study. The instrument of data collection was a semistructured self-developed questionnaire. Data collected from the Field was analyzed using descriptive statistic and parametric statistic (Simple Lineal Regression) at 0.05 level of significance. The result from the descriptive statistics revealed that most of the women used in the study, 97.41 per cent do not depend solely on their husband income. 63.70 cent of women spend all the money from their endeavour in taking care of their homes. 81.10 per cent of the women reported that they are able to contribute to the household and take care of themselves. From the parametric statistics carried out, result revealed a significant correlation between women involved in small business and household income and family wellbeing in Yala. The study thereby concludes that women in small business significantly contribute to household income and family wellbeing. The study calls for governmental effort towards improving the capacity of women in Yala through self-help programs and microcredit.
\end{abstract}

Keywords: Women; small business; household income; family wellbeing; Yala.

\section{Introduction}

According to the website, Country Meters (2020) women make up 50.5 per cent of the total African population but yet different level of economic advancement, cultural beliefs, social stigma and religious beliefs governs women participation in economic activities, labour market participation and compensation (Worldometer, 2020). globally, great strides and progress have been made in recent time on women participation in the labour market and income generation. But in Africa, the progress has been minimal due to cultural practices, gender discrimination and to an extent poverty (Worldometer, 2020). According to United Nation Women Document (2020), globally, more than 2.7 billion women are by law restricted from having or doing the same job as their male counterparts and most of them are from Africa. The United Nation (2018) study of 189 countries revealed that 108 of these nations still have laws preventing women from working in some specific jobs. Most of these Nations are found in Africa and the Middle East (World bank, 2018)

In sub-Sahara Africa, more than 95 billion dollars is lost yearly because of gender discrimination in the labour market. Though in the sub-region remarkable changes have been achieved in terms of closing the gender gap. in fact, six nations in African lead the way in gender reform and this nation are found in Sub-Saharan Africa. But yet, not more than 50 per cent of women in the subcontinent own bank accounts (World Bank Group, 2019). The report by Worldometer (2020), revealed that even with these reform women are still been excluded from manual jobs such as maintenance and construction. Patriarchal cultural practices and social structure still limit to the barest minimal

\footnotetext{
* Corresponding author.

E-mail address: erumaryiji@gmail.com (Mary Eru Iji)
} 
property rights and access to proceed from their labour and constrain their decision-making role (Jiggins, 1989). Also, Cultural norms and societal belief of the role of women in society do not often support women's involvement in economic activity and most aspiring women entrepreneurs do not have access to supportive members and necessary network. They also lack the negotiating power within their household (Campos, Frese, Goldstein, Iacovone, Johnson, McKenzie \& Mensmann, 2017; Ibiam, Bekomson, \& Angioha, 2020).

In Nigeria, women make up 49 per cent of the population and one in every four women in sub-Sahara Africa is Nigeria (world bank, 2019). This statistic provides the nation with human resources potentials, but the disparities in both economic and social opportunities have never been more obvious. According to the World Poverty Clock (2020), more than 94 million Nigerian now lives in extreme poverty, living under 1.90 dollars a day. Women, who are just under 50 per cent of the population, makeup 70 per cent of this figure. The country ranks 158 from 189 nation in the united nation's Human Development Index (UN, 2019) and this development index affect mostly women and girls.

In the labour market, women in the country are often consigned to the lower paying jobs than men (Anochie, Osuji, \& Anumudu, 2015; Ndem, Angioha \& Dike, 2020). According to the National Bureau of Statistics (2017) between 2010 and 2015, women only account for just 38 per cent employees in the public sector and just 14 per cent of 915 directors of board of companies quoted on the Nigerian stock exchange are women (Ihugba, Ukwunna, \& Obiukwu, 2019; Iji, Ojong \& Angioha, 2018). 7 out of every 10 Nigerian women do not have a bank account and more than half of Nigerian women are financially excluded (Fakoyejo, 2019). The world bank (2019) report that women in Nigeria are more likely to become entrepreneurs than men as a result of lack of opportunities in the labour market. But their entrepreneurship endeavours are more likely to be found in the informal sector where they are probably less likely to use more advanced business practices (world bank, 2019). In business decision making, women tend to take the less drastic approach as a result of gender-based constraints such as family and household factors and the kind of businesses they operate and their assets (Enfield, 2019). Women are also more likely to engage in the business sector with less growth rate. They also have less access to assets and capital to invest in any business venture (World Bank, 2019; Enfield, 2019).

There is a need to acknowledge the fact that there has been progress in closing the gender gaps. such as in the number school enrollment, health care access and labour force engagement (Mckinsey Global Institute, 2015; Proshare, 2018; Ekerebi \& Adeola, 2017; Olowa \& Adeoti 2014; Ukwayi, Angioha \& Ojong-Ejoh, 2018). The study of Adeyemi, Odusina and Akintoye (2016) reported an increase in overall female participation in the Nigeria labour market from 39.3 per cent in 1990 to 48.1 per cent in 2001. Despite these signs of progress made in the past few decades, gender equality is still a distant dream, as women still face discrimination in all socioeconomic area in life. The report by Oxfam And the Development Finance International (2019) list Nigeria last in the list of countries committed to achieving gender equality. The World Economic Forum (2018) ranked Nigeria 122 out of 144 nation in the global gender inequality gap. The gender inequality gap is not only just hindering women development but also that of the country. the McKinley report (2015) maintain that the gross domestic product of Nigeria could grow by $23 \%$ by 2025 if the labour market and economic inequality of the country is reduced to the barest minimum. Despite the social and economic banters that women face, they still contribute to household income and wellbeing especially in the rural areas.

In Yala Local Government Area, social and institutional norms, gender division of labour and patriarchal cultural practices restrict women participation in economic activities. Women have no choice but to become dependent on their spouses due to societal lack of acceptance of women engaging in most jobs that brings in income (Ugal, 2015). Women roles in the family are defined, they have limited house decision making power, have little access and control over household resources etc. But recent statistics has shown an increase in women participation in economic activities in Yala (Agba, Nkpoyen, \& Achima, 2011; NBS, 2019, Ojong-Ejoh, Iji \& Angioha, 2019). This increase in women participation in economic activities can be attributed to the increase in family poverty, government and its agencies provision of credit facilities as well as empowerment by nongovernmental agencies and donor agencies (Ugal, 2015). This study seeks to examine the extent to which women participation in economic activities has impacted on household income and wellbeing. 


\section{Literature Review}

The effect of women involvement in small business or women entrepreneurship on household income and family wellbeing has been established in literature. Seshie-Nasser and Odiro (2018) in their study tried to establish the correlation between women business ownership and household welfare in Ghana. Data for the study was derived from the national representative survey and analyzed using ordinary least square and 4 regression methods. The result from analyzed data revealed that small business owned by women is associated with improved household welfare. The study of Misango and Origiti (2013) assessed the roles of women entrepreneurs on poverty reduction in Kenya. Data was collected from 664 women entrepreneurs in Massai market in Nairobi Central Business District, using stratified and purposive sampling technique. The instrument of data collection was the questionnaire and interview. from the analyzed data, the result revealed a significant relationship between women entrepreneur and poverty reduction.

Deo, Kalisa and Theogene (2016) assessed the contribution of women entrepreneurs on the socio-economic wellbeing of rural people in Rwanda. stratified and simple random sampling technique was used to select women in the Eastern province of Rwanda. Data collected was analyzed using descriptive and correlation analysis. Result revealed a significant positive relationship between women entrepreneurs and socio-economic development. using the survey research method, Agbionu, Agbionu, Ikon, and Chinive (2015) assessed the relationship between women entrepreneurs and poverty alleviation in Awka, Anambra state. A sample of 450 female entrepreneurs was selected for the study. Analyzed data revealed a significant correlation between women entrepreneurs and poverty reduction. Abonge (2012) on the study in the North-West region of Cameroon, assessed the impact of women enterprise on household livelihood and survival. Data were collected from 45 female entrepreneurs through semi-structured interviews, focus group discussion and oral history from the data collected, it was discovered that women enterprise acts as a safety net for many households and are important for meeting the basic needs of the household.

\section{Methods}

\subsection{Study Settings}

Yala Local Government Area is one of the 18 Local Government Area in Cross River State, In Southern Nigeria. Home to Yala, Yache, Ukele, Gabu, Itekpe and Igede -edi people, the Local Government Area covers an area of $1739 \mathrm{~km}^{\mathrm{s}}$ and is the second most populated local government area in Cross River State, with a population of 210,843 according to the last census of 2006 (NPC, 2006). The local government area has its administrative headquarters at Okpoma and is further divided into 14 political wards that are administered by elected councillors (Age, Demonogu \& Ajumah, 2013). It was formally part of the old Ogoja Local Government and was created in 1991 by the General Ibrahim Babangida Administration. Yala is bordered to the east by Bekwara, to the North by Benue state, west by Benue state and the south by Ogoja local government Area.

The major economic activity of the local government Area is farming, trading and fishing. The local government also has a small number of civil servants working in various government agencies. Yala is mostly a rural area, hence most youths and able-bodied men migrate to cities for greener pastures leaving the women in the village. According to the last population census of 2006, the population of women in Yala stood at 106,141 accounting for 49.8 per cent of the total population.

\subsection{Study Design}

The quantitative survey method was adopted for this study, the method allows a researcher to collect data from a population or a subset of a population by posing a series of question (Attah \& Angioha, 2019; Angioha, Enukoha, Agba, \& Ikhizamah, 2020). in this study, a self-constructed questionnaire was used to elicit information for the study. The instrument was a 10-point structured questionnaire used to collect data from a sample of 317 drawn from a population of 106.141 women in Yala Local Government Area. The sample size was determined using Survey Monkey Determinant Technique at a 95 per cent confidence level and a margin of error of 4.5. 


\subsection{Participant Selection}

The participant for the study were selected using a stratified, convenience and random sampling technique. Yala Local Government Area was stratified into 10 according to the wards in the local government area. From this strata, 5 wards were selected using the convenience sampling technique. The convenience sampling was also used to select three wards, the selected wards are Yache, Yanakom, Yahe and Okpoma. From this wards, four communities were selected using convenience sampling. The researcher then used random sampling to select 40 participants from 6 communities and 39 from the other 6.

\subsection{Data Collection and Analysis}

Data for the study was collected within three months with the aid of four research assistants. The nature of the questions in the questionnaire made it easy for the researcher to distribute the instruments. All necessary ethical process was followed. A written consent letter was attached to each instrument and the researcher and each research assistant in the field verbally seek out the approval of participants before administering the instrument. All the instrument was collected except for which were either not returned or important information was not properly filled. These returned figures were used for analysis. Descriptive statistics such as tables. percentages and charts were used in presenting the data collected from the field. The study adopted a simple description to analyze the result

\section{Result and Discussions}

Data Collected from the field was analyzed using descriptive statistics before the result was then subjected to parametric statistics. The objective of the study is to examine the extent to which women involvement is small business contributes to household income and family wellbeing in Yala, Cross River State, Nigeria.

Table 1. Descriptive analysis of the response of respondents on extent to which women involvement is small business contributes to household income and family wellbeing

\begin{tabular}{llll}
\hline S/N & Items & Yes & No \\
\hline 1 & I am a full-time house wife & $7(2.59)$ & $263(97.41)$ \\
2 & I depend solely on what my husband provides to take care of the family & $9(3.33)$ & $261(96.67)$ \\
\hline
\end{tabular}

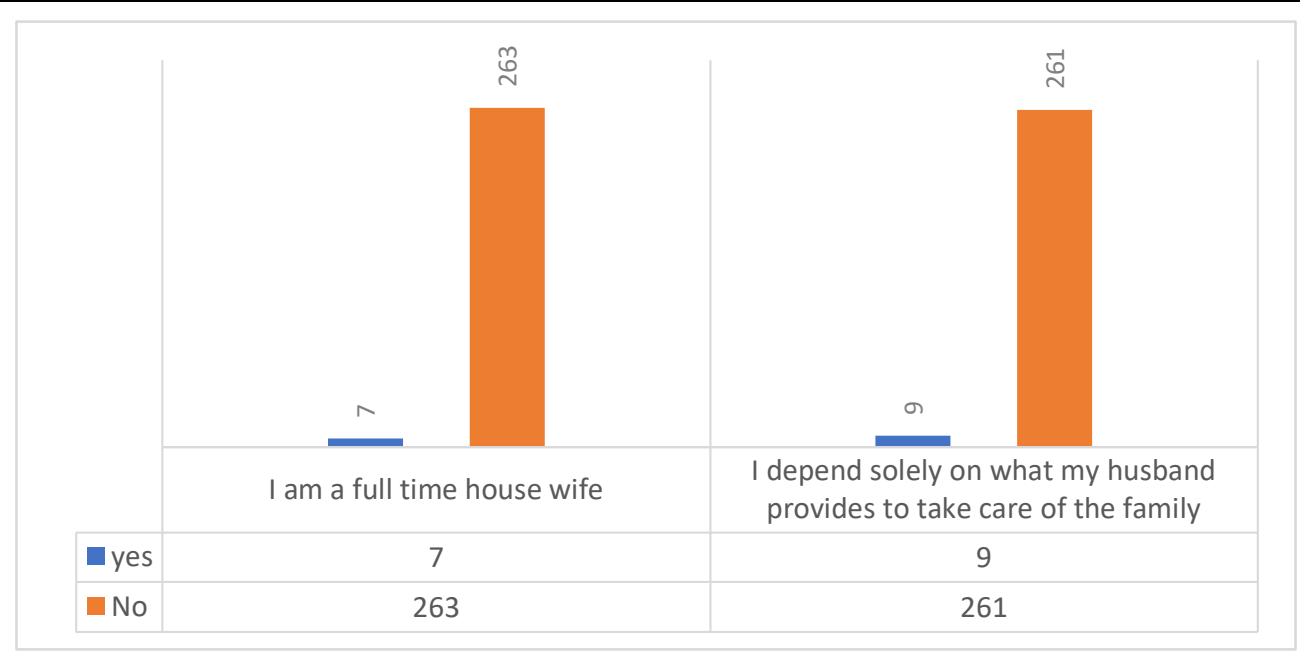

Fig. 1. Response on Extent to Which Women Involvement Is Small Business Contributes to Household Income and Family Wellbeing 
Table 2. Descriptive analysis of the response of respondents on extent to which women involvement is small business contributes to hou sehold income and family wellbeing

\begin{tabular}{lllllll}
\hline S/N & Item & $\begin{array}{l}\text { Sell farm } \\
\text { products }\end{array}$ & $\begin{array}{l}\text { Sell } \\
\text { Household } \\
\text { needs }\end{array}$ & $\begin{array}{l}\text { Operate a } \\
\text { leisure bar }\end{array}$ & work & $\begin{array}{l}\text { Full time } \\
\text { housewife }\end{array}$ \\
\hline 3 & $\begin{array}{l}\text { What do you do to assist in } \\
\text { taking care of the household }\end{array}$ & $114(42.22)$ & $80(29.63)$ & $41(15.19)$ & $28(10.37)$ & $7(2.59)$ \\
\hline
\end{tabular}

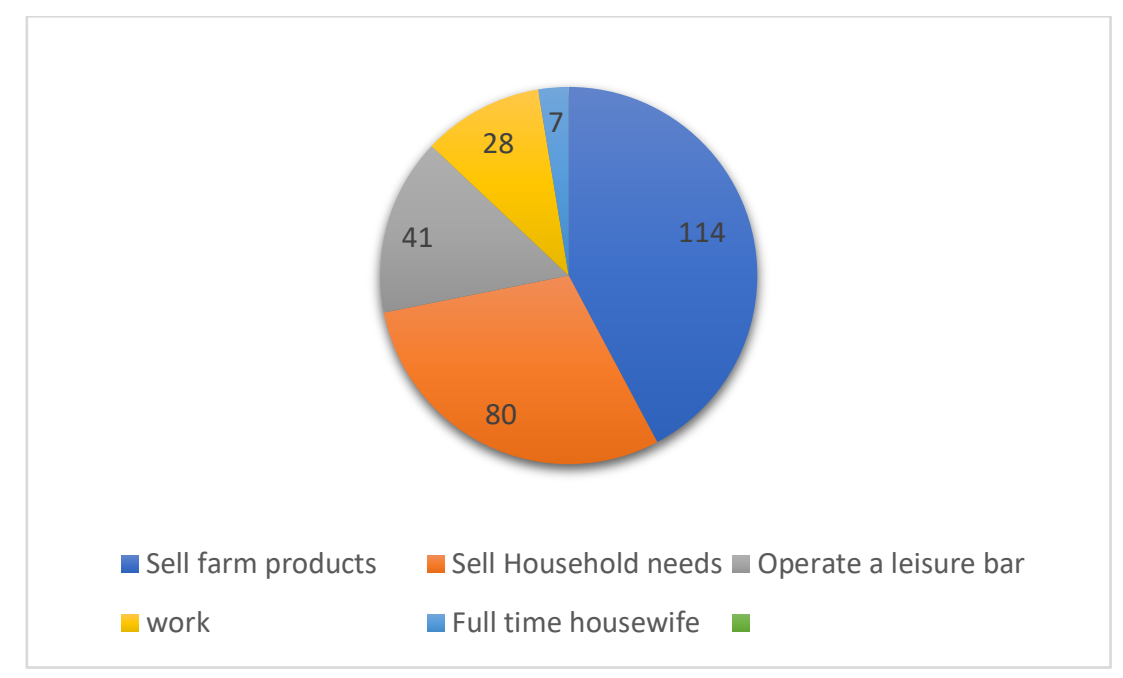

Fig. 2. Respondents Response on Extent to Which Women Involvement Is Small Business Contributes to Household Income and Family Wellbeing

Table 3. Descriptive analysis of the response of respondents on the extent to which women involvement is small business contributes to household income and family wellbeing

\begin{tabular}{lllllll}
\hline S/N & Item & $\begin{array}{l}\text { Less than } \\
25,000\end{array}$ & $\begin{array}{l}25,001 \text { to } \\
50,000\end{array}$ & $\begin{array}{l}50,001 \text { to } \\
75,000\end{array}$ & $\begin{array}{l}75,001 \text { and } \\
\text { above }\end{array}$ & $\begin{array}{l}\text { I do not } \\
\text { earn any } \\
\text { money }\end{array}$ \\
\hline 4 & How much do you make & $\begin{array}{l}159 \\
(58.89)\end{array}$ & $63(23.33)$ & $31(11.48)$ & $9(3.33)$ & $8(2.96)$ \\
\hline
\end{tabular}

\begin{tabular}{|c|c|c|c|c|c|c|c|c|}
\hline \multirow{2}{*}{\multicolumn{9}{|c|}{$\begin{array}{r}\text { I do not earn any money } \\
50,001 \text { to } 75,000\end{array}$}} \\
\hline & & & & & & & & \\
\hline c & 20 & 40 & 60 & 100 & 120 & 140 & 160 & 180 \\
\hline & $\begin{array}{l}\text { Less than } \\
25,000\end{array}$ & $\begin{array}{l}25,001 \text { to } \\
50,000\end{array}$ & $\begin{array}{l}50,001 \text { to } \\
75,000\end{array}$ & $\begin{array}{l}75,001 \text { and } \\
\text { above }\end{array}$ & $\begin{array}{l}\text { I do not } \\
\text { earn any } \\
\text { money }\end{array}$ & & & \\
\hline How much do you make & 159 & 63 & 31 & 9 & 8 & & & \\
\hline
\end{tabular}

Fig. 3. Response on Extent to Which Women Involvement Is Small Business Contributes to Household Income and Family Wellbeing 
Table 4. Descriptive analysis of the response of respondents on the extent to which women involvement is small business contributes to household income and family wellbeing

\begin{tabular}{lllllll}
\hline S/N & Item & $\begin{array}{l}\text { All the } \\
\text { money I } \\
\text { earn }\end{array}$ & $\begin{array}{l}\text { Less than } \\
25,000\end{array}$ & $\begin{array}{l}25,001 \text { to } \\
50,000\end{array}$ & $\begin{array}{l}50,001 \text { to } \\
\text { above }\end{array}$ & $\begin{array}{l}\text { I don't } \\
\text { contribute to the } \\
\text { household }\end{array}$ \\
\hline 5 & $\begin{array}{l}\text { What do you contribute to } \\
\text { your household }\end{array}$ & $172(63.70)$ & $76(28.15)$ & $12(4.44)$ & $2(0.74)$ & $8(2.96)$ \\
\hline
\end{tabular}

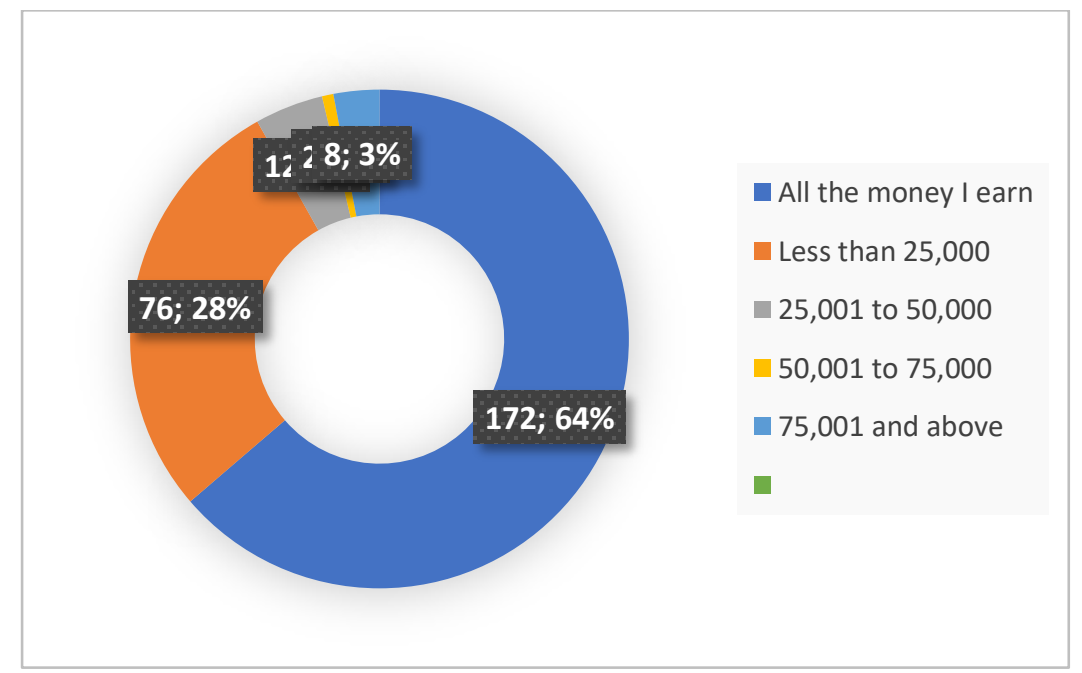

Fig. 4. Response on Extent to Which Women Involvement Is Small Business Contributes to Household Income and Family Wellbeing

Table 5. Descriptive analysis of the response of respondents on the extent to which women involvement is small business contributes to household income and family wellbeing

\begin{tabular}{|c|c|c|c|c|c|}
\hline $\mathrm{S} / \mathrm{N}$ & Item & Agreed & $\begin{array}{l}\text { Strongly } \\
\text { Agreed }\end{array}$ & Disagreed & $\begin{array}{l}\text { Strongly } \\
\text { Disagreed }\end{array}$ \\
\hline 6 & $\begin{array}{l}\text { With the money, I make from my endeavours } \\
\text { I can complement what my husband brings } \\
\text { home }\end{array}$ & $133(49.25)$ & $114(42.22)$ & $13(4.81)$ & $10(3.70)$ \\
\hline 7 & $\begin{array}{l}\text { I can contribute to the household and take care } \\
\text { of my self }\end{array}$ & $128(47.40)$ & $91(33.70\}$ & $33(12.22)$ & $18(6.66)$ \\
\hline 8 & $\begin{array}{l}\text { Since I started making money from my } \\
\text { endeavour my husband does not contribute to } \\
\text { the upkeep of the house as he is supposed to }\end{array}$ & $\begin{array}{l}71 \\
(26.30)\end{array}$ & $\begin{array}{l}76 \\
(28.14)\end{array}$ & $\begin{array}{l}66 \\
(24.44)\end{array}$ & $\begin{array}{l}57 \\
(21.11)\end{array}$ \\
\hline 9 & $\begin{array}{l}\text { My spouse can save and plan for the future } \\
\text { because of my contribution to the family } \\
\text { income }\end{array}$ & $\begin{array}{l}88 \\
(32.50)\end{array}$ & $\begin{array}{l}82 \\
(30.37)\end{array}$ & $\begin{array}{l}66 \\
(24.44)\end{array}$ & $\begin{array}{l}34 \\
(12.50)\end{array}$ \\
\hline 10 & $\begin{array}{l}\text { My household is doing well because of my } \\
\text { financial contribution }\end{array}$ & $\begin{array}{l}135 \\
(50.00)\end{array}$ & $\begin{array}{l}112 \\
(41.50)\end{array}$ & $\begin{array}{l}13 \\
(4.81)\end{array}$ & $\begin{array}{l}10 \\
(3.70)\end{array}$ \\
\hline
\end{tabular}




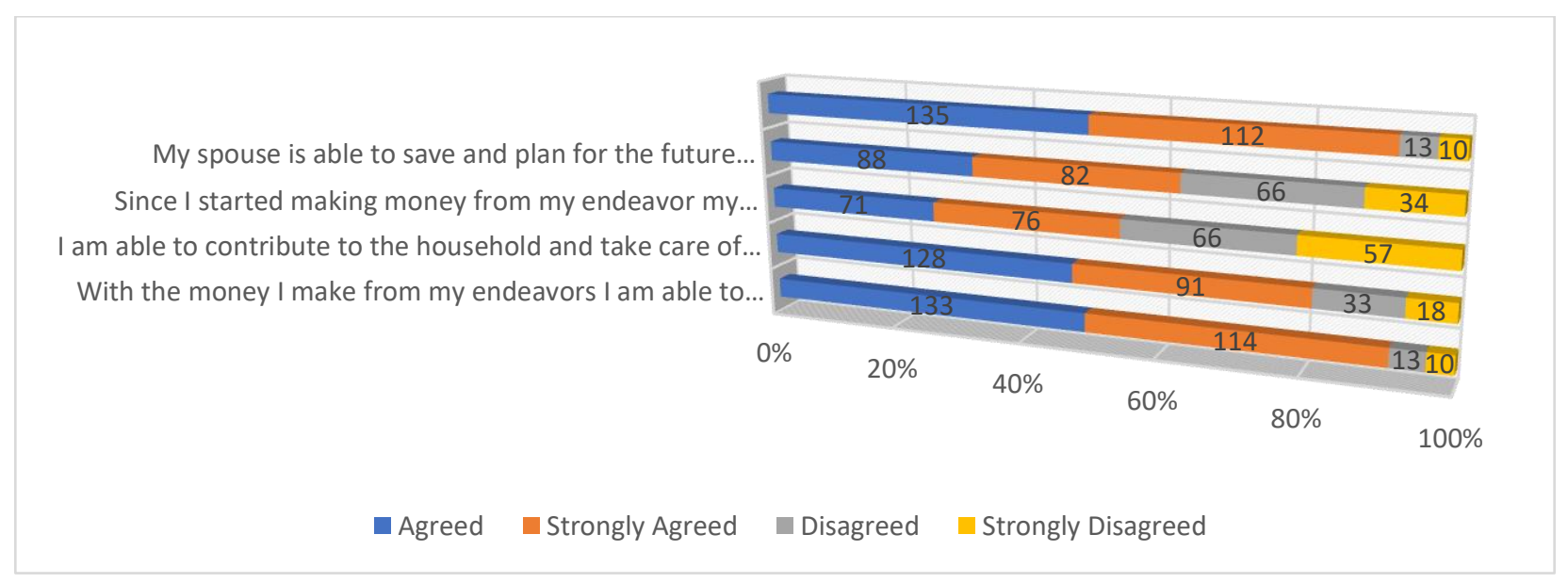

Fig. 5. Response on Extent to Which Women Involvement Is Small Business Contributes to Household Income and Family Wellbeing

Descriptive analysis according to the response of the respondents revealed thus; on I am a full-time housewife, 97.41 per cent of the respondent reported No and only 2.59 per cent reported Yes. On I depend solely on what my husband provides to take care of the family; 96.67 per cent of the respondents reported No, while only 3.33 per cent reported Yes. On what do you do to assist in taking care of the household; 42.22 per cent of the respondents reported selling farm product, 29.63 per cent reported selling household needs, 15.19 per cent reported operating a leisure bar, 10.37 per cent reported working and 2.59 per cent reported been full time housewife. On how much do you make; 58.89 per cent of the respondents reported less than \#25,000, 23.33 per cent reported between \#25,001 and \#50,000, 11.48 per cent of the respondents reported between \#50,001 and \#75,000, 3.33 per cent reported \#75,000 and above and 2.96 per cent reported nor earning any money. On what do you contribute, 63.70 per cent reported all their earnings, 28.15 per cent reported less than \#25,000, 4.44 per cent reported spending between \#25,001 and \#50,000, 0.74 per cent reported \#50,001 and above and 2.96 reported not contributing their earnings. On with the money I make from my endeavours I can complement what my husband brings home; 49.25 per cent reported agreed, 42.22 per cent reported strongly agreed, 4.81 per cent reported disagreed and 3.70 per cent reported strongly disagreed. On I can contribute to the household and take care of myself: 47.40 per cent of the respondents reported agreed, 33.70 per cent reported strongly agreed, 12.22 per cent reported disagreed and 6.66 reported strongly disagreed. On since I started making money from my endeavour my husband does not contribute to the upkeep of the house as he is supposed to;26.30 per cent of the respondents reported agreed, 28.14 per cent reported strongly agreed, 24.44 per cent reported disagreed and 21.11 per cent reported strongly disagreed. On my spouse can save and plan for the future because of my contribution to the family income; 32.50 per cent of the respondents reported agreed, 30.37 reported strongly agreed, 24.44 per cent reported disagreed and 12.50 per cent strongly disagreed. On my household is doing well because my financial contribution; 50.00 per cent reported agreed, 41.50 reported strongly agreed, 4.81 reported disagreed and 3.70 per cent reported strongly disagreed.

\subsection{Parametric Analysis}

Result from the descriptive statistic was subjected to simple lineal Regression to check the correlation between women involved in small business and household income and family wellbeing. The independent variable here is women involved in small business, while the dependent variable is family income and household wellbeing

Table 6. Summary simple linear regression analysis of the relationship between women involvement in small business and family income, household wellbeing

\begin{tabular}{lccc}
\hline Variables & Mean & & Std. Deviation \\
Women Small Bus. & & 13.625 c & 3.27161 \\
Family income and household wellbeing & 39.8444 & 12.52380 \\
\hline
\end{tabular}




\begin{tabular}{lrrrrrrr}
\hline Model & & Sum of Squares & Df & F & R & R Square Adjusted R & Sig \\
& & & Square & \\
\hline Regression & 2432.202 & 1 & 29.424 & $0.240^{\mathrm{a}}$ & 0.058 & 0.054 & $0.000^{\mathrm{a}}$ \\
Residual & 39759.262 & 268 & & & & & \\
Total & 42191.467 & 269 & & & & & \\
\hline
\end{tabular}

The data analyzed using the result from the descriptive analyses result revealed that the R-value of 0.240 is significant at 0.05 alpha level $(p=0.000<0.05)$, this result implies that there exists a statistically significant correlation between women involvement in small business and family income, household wellbeing. Also, from the analyzed data, the result revealed an $\mathrm{R}^{2}$-value of .058 . This implies that $58 \%$ of the total variance in family income, household wellbeing is accounted for by predictor variable (women involvement in small business). Also, the Regression ANOVA revealed a moderate joint linear association (contribution) of the predictor women involvement in small business and family income, household wellbeing given by the $F(1,268)=29.424$; $p<0.05$. The adjusted $R^{2}(.054)$ shows some shrinkage of the unadjusted value (.058) indicating that the model could be generalized on the population. Based on the result, the study concluded that women involvement in small business significantly improves family income and the wellbeing of the family.

\subsection{Discussion of Findings}

The study is aimed at examining the extent to which women involvement is small business contributes to household income and family wellbeing in Yala, Cross River State, Nigeria. From the descriptive analysis carried out, it was discovered that women involvement in small businesses has helped improve the wellbeing of the family and also improve the income of their household. The descriptive result revealed that most women in the area do not depend on the sole income of their husband or male spouse for home welfare. This is because 97.41 per cent of the study participants are not full-time housewives, 96.67 per cent do not depend solely on what their spouse brings home for family income and welfare, most of them engage in various economic activities to support their home. Most of the participant (42.22 per cent) deal on farm produce. This can be attributed to the fact that Yala, is mostly rural, and the major occupation of the inhabitants is agriculture. Other participants are involved in household needs (29.63 per cent), operate a leisure bar (15.19 per cent), employed (10.37 per cent) and 2.59 per cent are full-time housewives.

On the amount of income that the participants make from their small business, 58.89 per cent make between zero and 25,000 naira. The low rate of income can be attributed to a saturated market and the kind of small business that the women engage in. Yala as a rural community is inhabited by mostly farmers, hence most of the women are engaged in selling farm produce. Since the market is not much, the middlemen tend to take advantage and buy at very low prices. 23.33 per cent of the participants make between 25,001 naira and 50,000 naira, 11.48 per cent make between 50,001 and 75,000, 3.33 per cent make between 75,001 and above, while 2.86 do not make any money at all. Most of the participants, 63.70 per cent, reported spending all their earnings from their small business on their family and household. This can be attributed to the fact that the lack of industrialization of rural areas have rendered most of their inhabitants unemployed. And with the large family size that common in Northern Cross River State, couples tend to spend all the money they make on the family. The descriptive analysis also revealed that with the small business that they own, most participants, 81.10 per cent have been able to contribute to the wellbeing of their home as well as care for themselves. The result also revealed that most of the households (62.87 per cent) are able to save because both spouses are employed and contributing to the wellbeing of the family.

The result from the descriptive statistics was then subjected to simple lineal Regression at 0.05 level of significance. From the analysis, it was discovered that a significant positive relationship exists between women involvement in small business and family income, household wellbeing. This was because the R-value of .240 is significant at 0.05 alpha level $(\mathrm{p}=0.000<0.05)$. Also, the regression ANOVA revealed a moderate joint linear association (contribution) of the predictor women involvement in small business and family income, household wellbeing given by the $\mathrm{F}(1,268)=29.424 ; \mathrm{p}<0.05$. The adjusted $\mathrm{R}^{2}(.054)$ shows some shrinkage of the unadjusted value $(.058)$. the 
analyzed data also revealed an $\mathrm{R}^{2}$-value of .058 , implying that $58 \%$ of total variance in family income, household wellbeing is accounted for by predictor variable (women involvement in small business). This finding corroborates those of Abonge (2012), Seshie-Nasser and Odiro (2018), Misango and Origiti (2013), Deo, Kalisa and Theogene (2016) and Agbionu, Agbionu, Ikon, and Chinive (2015). Abonge (2012) found that women enterprise acts as a safety net for many households and important for meeting the basic needs of the household. The study of Agbionu, Agbionu, Ikon, and Chinwe (2015) on the correlation between women entrepreneurs and poverty alleviation in Awka, Anambra state found a significant positive correlation between women entrepreneurs and poverty alleviation. The study of Deo, Kalisa and Theogene (2016), found a significant positive relationship between women entrepreneurs and socioeconomic development. Abonge (2012) examined the impact of women enterprise on household livelihood and survival. Result revealed that women enterprise acts as a safety net for many households and are important for meeting the basic needs of the household. Seshie-Nasser and Odiro (2018) in their study found that small business owned by women is associated with improved household welfare.

\section{Conclusion and Recommendation}

The findings of this study have shown that women involvement in small business contributes significantly to household income and family wellbeing in Yala. This finding clearly shows the untapped potentials of women in rural areas. For most rural women, engaging in small businesses and other entrepreneurship endeavours is part of a broader survival strategy and a means of supporting the household. They always engage in these businesses on part-time bases, in a saturated market and low-income return businesses. Hence. there is need for the government at all level to strengthen the capacity of women organization and cooperative in rural areas through the provision of credit facilities in the form of soft loans and grants that will serve the need of their members as it affects their businesses. Also, there is need for the government to create awareness among the financial organization and aid agencies about women entrepreneurs needs in rural areas, to provide accessibly appropriate and flexible financial service to aid their businesses and business intention.

\section{References}

Abonge, C. V. (20012). Assessing the impact of women's enterprises on household livelihoods and survival: Evidence from the North West Region of Cameroon. Greener Journal of Social Sciences ,2 (5), pp. 147 159 ,

Adeyemi, O. E., Odusina, K. E. \& Akintoye, A. E. (2016). Religion and Labor Force Participation in Nigeria: Is there any Inequality among Women? African journal of reproductive health 20 (3), 75-84

Agba A. M. O., Nkpoyen, F. \& Achima, M. N. (2011). women self-help initiatives: a paradigmatic shift in rural development approach in cross river state, Nigeria. International Journal of Development and Management Review (INJODEMAR) Vol. 6, (1), 50-61

Agbionu, E. O., Agbionu, C. U., Ikon, M. A. \& Chinwe, O. V. (2015) Women Entrepreneurship and Poverty Alleviation in Awka Metropolis. Organiz Manag 4: 158. doi:10.4172/2169-026X.1000158

Angioha, P. U., Enukoha, C. U., Agba, R. U., \& Ikhizamah, G. U. (2020). Information Technology Predictor Variables and Employee Productivity in Commercial Banks. JINAV: Journal of Information and Visualization, 1(1), 44-52. https://doi.org/10.35877/454RI.jinav178

Anochie, U.C., Osuji, C. O. \& Anumudu, C. N. (2015). Effect of gender inequality on economic growth in Nigeria. International al Journal of Current Research, 7(9) 789-806

Attah, F. M. \& Angioha, P. U. (2019); Examining the Level of Relationship Between Working Condition Predictor Variables; Remuneration, Working Hours, Office Design, Job Security and Workers Wellbeing and Productivity in Commercial Banks. International Journal of Scientific and Research Publications (IJSRP), 9(5), DOI: http://dx.doi.org/10.29322/IJSRP.9.05.2019.p896. 
Campos, F., Frese, M., Goldstein, M., Iacovone, L., Johnson, H. C., McKenzie, D., Mensmann, M. (2017). Teaching personal initiative beats traditional training in boosting small business in West Africa Science 357, 12871290 https://science.sciencemag.org/content/sci/357/6357/1287.full.pdf

Country Meters (2020). Africa Population clock. https://countrymeters.info/en/Africa

Deo, M., Kalisa, F. \& Theogene, H. (2016)." The Contribution of Women Entrepreneurship in Family SocioEconomic Development in Rural Areas, Rwanda," International Journal of Innovation, Management and Technology vol. 7, no. 6, pp. 256-259, 2016.

Ekerebi E. \& Adeola, O. (2017) Estimation of the Difference in Agricultural Yield Between Male and Female Farmers in Nigeria. Feed the Future Innovation Lab for Food Security Policy Research Brief No $28 I$ https://www.nigeriaagriculturalpolicy.net/2017/10/03/nn

Enfield, S. (2019). Gender Roles and Inequalities in the Nigerian Labour Market. K4D Helpdesk Report. Brighton, UK: Institute of Development https://assets.publishing.service.gov.uk/media/5d9b5c88e5274a5a148b40e5/597_Gender_Roles_in_Nigeria n_Labour Market.pdf

Fakoyejo, O. (2019). Here's why women are financially excluded in Nigeria. A new report by the CBN and EFInA has unravelled the reason for the gender gap in financial access in Nigeria. https://nairametrics.com/2019/12/13/heres-why-women-are-financially-excluded-in-nigerial

Ibiam, A. A, Bekomson, E. M. \& Angioha, P. U. (2020). Socio-Environmental Factors as Determinants of Social Wellbeing of Adolescents in Calabar, Cross River State, Nigeria. European Journal of Public Health Studies, 1(2). http://doi.org/10.5281/zenodo.3597522

Ihugba, O. A., Ukwunna, J. C., \& Obiukwu, S. (2019). Government education expenditure and primary school enrolment in Nigeria: An impact analysis. Journal of Economics and International Finance, 11(3), 24-37.

Iji, M. E., Ojong, F. \& Angioha, P. U. (2018). Microfinance Credit Programmes: Implications on Poverty Reduction in Southern Senatorial District of Cross River State, Nigeria. IOSR Journal of Humanities and Social Science (IOSR-JHSS) Volume 23, Issue 6, Ver. 6 (June. 2018) PP 38-45.

Jiggins, J. (1989). 'How poor women earn income in sub-Saharan Africa and what works against them', World Development, 17(7): 953-963

McKinsey Global Institute (MGI) (2015). The Power of Parity: How Advancing Women's Equality Can Add $\$ 12$ Trillion To Global Growth. https://www.mckinsey.com/ /media/McKinsey/Industries/Public\%20and\%20Social\%20Sector/Our\%20Insig hts/How\%20advancing\%20womens\%20equality\%20can\%20add\%2012\%20trillion\%20to\%20global\%20gro wth/MGI\%20Power\%20of\%20parity_Executive\%20summary_September\%202015.pdf

Misango, S.B. \& Ongiti, O.K. (2013), "Do women entrepreneurs play a role in reducing poverty? A case in Kenya", International Review of Management and Business Research, Vol. 2 No. 1, pp. 87-103.

National Bureau of Statistics (2017). Statistical Report on Women and Men In Nigeria, https://nigerianstat.gov.ng/elibrary?queries\%5Bsearch\%5D=statistical\%20report\%20on\%20women\%20an d\%20men

Ndem, M. A., Angioha, P. U. \& Dike, E. (2020). Improving the Socio-Economic Wellbeing of Rural People: Analysis of the Impact of the Community and Social Development Project (CSDP) tn Odukpani Local Government Area of Cross River State, Nigeria. Asian Journal of Applied Sciences.8 (2), 88-94.

Ojong-Ejoh, M. U., Iji, M. E., Angioha, P.U. (2019). Curing Socio-Economic ILLS in Obudu Local Government Area: An Assessment of Non-Governmental Agencies Activities". Journal of Social Service and Welfare;1(2): 38-45. 
Olowa, O., \& Adeoti, A., (2014). Effect of Education Status of Women on Their Labour Market Participation in Rural Nigeria. American Journal of Economics, 4(1): 72-81 DOI: 10.5923/j.economics.20140401.07

Oxfam and Development Finance International (2019). The Commitment to Reducing Inequality Index. A new global ranking of governments based on what they are doing to tackle the gap between rich and poor. https://wwwcdn.oxfam.org/s3fs-public/file_attachments/rr-commitment-reduce-inequality-index-170717-en.pdf

Proshare (2018) Informal Economy and Poverty Reduction in Nigeria https://www.proshareng.com/news/NIGERIA\%20ECONOMY/Informal-Economy-and-PovertyReduction-inNigeria/41237

Proshare (2018) Informal Economy and Poverty Reduction in Nigeria https://www.proshareng.com/news/NIGERIA\%20ECONOMY/Informal-Economy-and-PovertyReduction-inNigeria/41237

Seshie-Nasser, H. A., \& Oduro, A. D. (2018). Women-owned businesses and household welfare. International Journal of Gender and Entrepreneurship. doi:10.1108/ijge-01-2018-0001

Ugal, D. B. (2015). Socio-economic background and women empowerment in cross river state, Nigeria: implications for maternal health, using data from the NDHS 2008. Sociology and Anthropology, 3(11), 591- 597. https://doi.org/10.13189/sa.2015.031103

Ukwayi, J. K., Angioha, P. U. \& Ojong-Ejoh, M. U. (2018). Youth empowerment: A criminological approach for crime prevention and control in Cross River State, Nigeria. IOSR Journal of Humanities and Social Science (IOSR-JHSS), 22 (11), 73-81.

United Nation (2018). The Sustainable Development Goals Report. https://unstats.un.org/sdgs/files/report/2018/TheSustainableDevelopmentGoalsReport2018-EN.pdf

United Nation women document (2020). Facts and Figures: Economic Empowerment, Benefits of economic empowerment. https://www. unwomen.org/en/what-we-do/economic-empowerment/facts-and-figures

World Bank (2018). World Employment Social Outlook. Trends 2018. https://www.ilo.org/wcmsp5/groups/public/--dgreports/---dcomm/---publ/documents/publication/wcms_615594.pdf

World Bank Group (2019) Profiting from Parity: Unlocking the Potential of Women's Business in Africa. https://openknowledge.worldbank.org/handle/10986/3142

World Economic Forum (2018). The Global Competitiveness Report. Insight Report. http://www3.weforum.org/docs/GCR2018/05FullReport/TheGlobalCompetitivenessReport2018.pdf

Worldometer (2020). Population by Gender, Age, Fertility Rate, Immigration. https://www.worldometers.info/worldpopulation/world-population-gender-age.php 